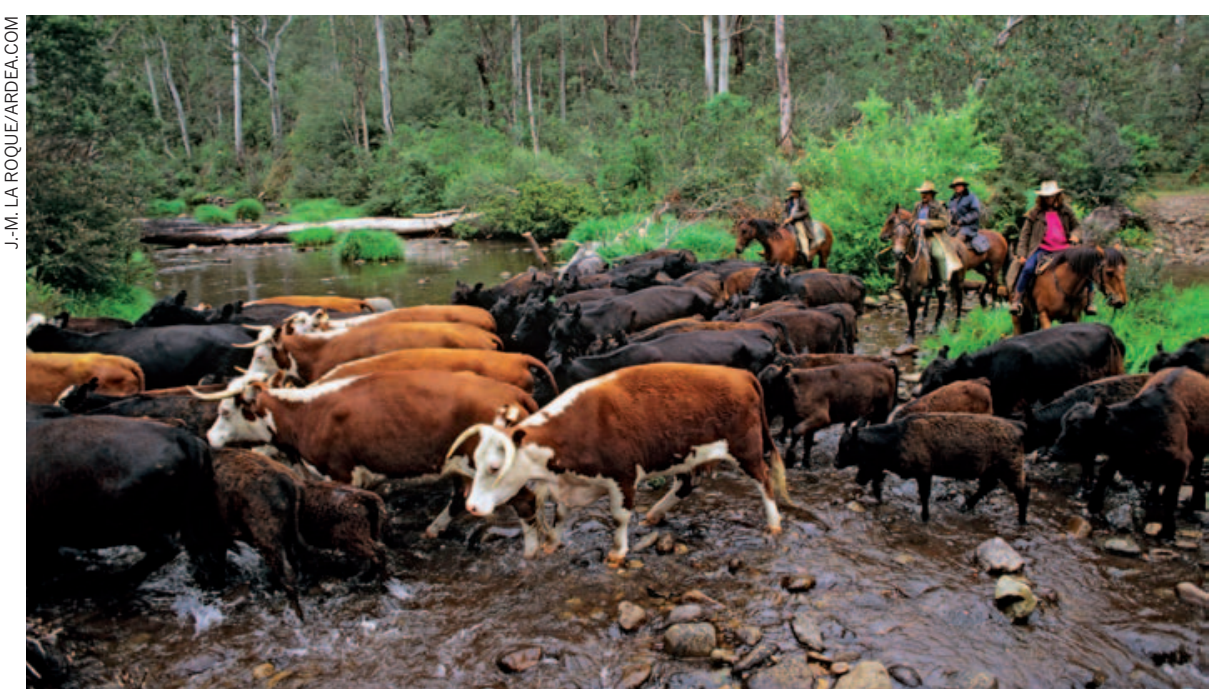

Cattle have been released into parts of Australia's Alpine National Park, despite a ban on grazing there.

ECOLOGY

\title{
Australian grazing trial ignites debate
}

\section{Researchers question science behind controversial effort to examine cattle's role in controlling bushfires.}

\section{BY EMMA MARRIS}

\section{$\mathrm{T}$} o ecologists overseas, the invitation might sound tempting. It offers travel to Australia and unspecified remuneration to serve on an advisory panel considering a juicy scientific question: could allowing cattle to graze in the country's Alpine National Park - the picturesque setting for the film The Man from Snowy River - reduce the risk of bushfires? Those responding to the call, issued by the federal state of Victoria at the beginning of March, might not realize that it also involves walking into a serious stoush - that's Australian for fight.

More than 100 Australian ecologists have signed a letter to the Australian government denouncing the trial. The letter's organizers claim that the trial is a naked attempt to use the imprimatur of science to allow cattle to graze in an ecologically sensitive area, and they now fear that international scientists ignorant of the ruse will be duped into lending credibility to the project. "It's a misuse of the word science to justify a political decision," says Georgia Garrard, an ecologist at the University of Melbourne who helped to organize the protest letter.

The decision in question is the return of cattle to portions of the 646,000-hectare park, a landscape of deep ravines, high plateaux and snow gum trees. The move fulfils a campaign pledge by Victoria's centre-right coalition, which was narrowly elected last November.

In the 1950s, as many as 100,000 head of Aberdeen Angus and Hereford grazed in the park, according to Mark Coleman, president of the Mountain Cattlemen's Association of Victoria. Gradual restrictions since then culminated in a park-wide grazing ban in 2005 after a Victoria government review found that cattle didn't reduce the intense wildfires that can visit the region, but that their hooves, grazing and manure damage sensitive wetland ecosystems.

Coleman says that the cattle do stop fires, by eating the vegetation that forms potential fuel, and that ecologists have ignored mountain cattlemen's knowledge of the land. "We've got generational knowledge that goes back - 150 years in my family. You can't buy that knowledge; you can't learn it in a university."

In January, when 400 head of cattle were allowed back into the park, the government of Victoria announced that they were part of a research trial. Opponents of the move argue that no baseline data were taken and that the trial has not been designed. Designing the trial will be one of the advisory panel's tasks, says Peter Appleford, executive director of forests and parks for Victoria. He defends the lack of baseline data, saying that, for a large landscape-scale trial, such data would need to have been kept for decades to be relevant. "Some of these scientists have been trained on small plots and don't understand landscapescale experiments," he adds.

Libby Rumpff, an ecologist at the University of Melbourne and an organizer of the scientific protest, disagrees. "It doesn't matter what scale you are looking at, you should be collecting baseline data," she says.

The Melbourne newspaper The Sunday Age has charged the Victoria government with trying to blackmail the University of Melbourne into participating in the trial by threatening its state funding, a charge the government denies. And John DuBois, a spokesman for the university, says that researchers at its School of Land and Environment have told the government that the trial may amount to repetition of previous work. The university has no plans to participate directly.

Mark Adams, an ecologist at the University of Sydney, has been invited by the Victoria government to "lead the program of research that will accompany" the trial, according to Victoria's website. Adams says that no contract has been signed between the university and the government, "and without a contract I won't be doing anything". If a contract is signed, he adds, he won't be designing a trial, but merely "testing methods suitable for measuring the impact of cattle on fuels and on ecosystem functions". Adams says that he has taken a lot of flak for his willingness to work with Victoria, but feels that academics "have a duty to work with government to try to get the best outcomes in the public interest".

On 18 March, Tony Burke, Australia's environment minister, demanded that the state ask the federal government for approval to release the cattle. The demand means that the cattle must be removed from the park until the federal government has reviewed the matter. But even without this demand, the animals' time in the highlands is almost up. Winter snows will arrive soon, and the cattle would have been taken down from the mountains by midApril anyway. Furthermore, it is not clear what the federal decision means for the "excellent international candidates" who Appleford says have already applied to sit on the advisory panel.

The point of the episode, says Garrard, is "that science shouldn't be misused for political gain”. Coleman sees both sides as politicized. The ecologists have been "indoctrinated" by politicians on the left, he says, whereas the coalition is trying to deliver on a political promise. "Ninety per cent of the general public couldn't give a shit about the cattle or the environment," he says. "At the end of the day, it is all politics." - 